\title{
7 Making it in academia: A study of career narratives of men and women professors in Norway and Japan
}

\author{
Vivian Anette Lagesen, Guro Korsnes \\ Kristensen, Siri Øyslebø Sørensen, \\ and Derek Matsuda
}

\section{Inclusion into professorships}

Professorships are hard to achieve in most countries for both men and women due to a scarcity of permanent positions in academia (Fumasoli et al., 2015). Becoming a professor means entering the academic sphere and then competing for funding and positions to stay in often-precarious job situations for many years. What facilitates and/or hinders researchers' trajectories toward professorships? In this chapter we investigate how men and women professors in Norway and Japan account for their career trajectories with an emphasis on what has helped them persevere and manage to stay in academia. The aim is to contribute insights on what are important inclusion factors and whether, and if so, in what ways, these are gendered and contextual in becoming a professor in Norway and Japan.

Whereas increasing numbers of women are entering universities, the proportion of women in full professor positions has remained disproportionately low in most countries, including Norway and Japan. In Norway, women constitute $34 \%$ (Tungesvik, 2021) of all full professorships and, in Japan, only 10\% (Gender Equality Bureau Cabinet Office, 2015 , p. 87). Clearly, academic careers do not unfold in identical manners across national contexts, and individuals are not independent from local, institutional and national contexts (Le Feuvre et al., 2019). Thus, it is interesting to explore factors that are emphasised by men and women professors as important for becoming professors in two contexts as different as Norway and Japan. Since there are clearly many potential factors playing in, our study is predominantly an explorative one where we ask: What do men and women professors consider the most important factors for entering and managing their career in academia?

We shall start by consulting literature on what has been found to be important for entering and sustaining careers in academia. A substantial part of this literature is from a Western context. However, we shall also outline the main features of the national contexts for Norway and Japan for making an academic career. Then we present our analysis of the empirical 
data. In the discussion, we reflect on how the inclusion factors that were emphasised in our interviewees' accounts should be understood in a larger societal and scholarly perspective.

\section{Research on entering and sustaining academic careers}

Early efforts to study professors (who were usually men) focused on psychosocial aspects, like early childhood experiences, background variables and personality traits (Lindholm, 2004). Later, studies of professor careers (still usually of men) have pursued a class perspective emphasising cultural and social capital (Bourdieu, 1988). Another strand of studies is concerned with social cognitive factors, such as the combination of self-efficacy and expectations of outcome and goals (Lent et al., 1994). For example, professors in Lindholm's study (2004) from the US spoke of a 'true calling' and a 'match' between them and academia (pp. 611-24). Studies of academics have often found that a passion for academic work, an appreciation for being in an academic job and flexibility are important drivers for staying in academia. In Riordan's (2011) study of senior academics from six different countries, opportunities for individual expression and autonomy were emphasised. According to Cannizzo (2018), discourses of 'passionate' labour, self-authenticity and personal freedom are central to how academics talk about and govern their work.

Another factor often stressed as important for entering and remaining in academia is cultural and social capital (Bourdieu, 1988), the former particularly in the form of an academic family background. A study from the Netherlands (Van Balen et al., 2012) found that social capital (via mentorship and network) was more important academic background for whether talented academics stayed or left academia. Social capital may include social networks, but also people who help and support to remain and advance in academia (Van den Brink \& Benschop, 2014; Etzkowitz et al., 2000; Heffernan, 2020). Mentorship and supervisors have been found to be of crucial importance for academic advancement (Blackburn et al., 1981; Van Balen et al., 2012). Another aspect often found to increase the probability of succeeding in academia is a willingness to be geographically mobile, due to increased competition and internationalisation (Kim, 2017; Ortlieb \& Weiss, 2018). Being transnational has also been seen as constitutive for academic identities. Nonaka (2020) has reflected on how her transnational research career influenced her identity as a Japanese woman professor and helped her advance. A study by Cohen et al. (2020) from New Zealand has shown how discourses of academic mobility were considered essential to academic work but that heteronormative discourses of motherhood produce gender inequities in academic mobility.

While most studies on inclusion in academic career inclusion in the Western context have comprised predominantly studies of men, studies of women in academia have mainly focused on exclusion (also in a Western 
context). One argument is that academia is a 'greedy' line of work which makes for a difficult work-life balance because of traditional household divisions and caring responsibilities (Ivancheva et al., 2019; SalminenKarlsson et al., 2018; Ward \& Wolf-Wendel, 2012; Ylijoki, 2013). Family situations and caring responsibilities have been seen as an important reason for why women opt out of academia (Acker \& Armenti 2004; Van Anders, 2004). Women who remain in academia have been found to struggle with parental guilt and a sense of work-life imbalance (Castaneda \& Isgro, 2013; Dubois-Shaik \& Fusulier, 2017; Ghodsee \& Connelly, 2011). However, studies suggest that having children does not seem to affect scientific output as such (Aiston \& Jung, 2015; Heijstra et al., 2015). This is also the case in Norway, where the combination of an academic career and childcare has been more common than in other countries (Vabø et al., 2014). Here, a study showed that having children has not seemingly affected scientific output for Norwegian women academics, while it had a positive effect on the scientific output for Norwegian men (Hovdhaugen et al., 2004).

Much literature has focused on how many women have been and continue to be disadvantaged through institutional, cultural and organisational forces at work in academic settings (see, e.g., Fox et al., 2017). Gender discrimination, sexual harassment and sexism have been seen to impact women's careers, and the term 'chilly climate' has been used to describe the alienation and isolation reported by women (Bevan \& Learmonth, 2012; Britton, 2017; Savigny, 2014) - not only on the basis of their gender, but also their class, race and ethnicity (Essed, 2004; Gutierrez et al., 2012; Ostrove et al., 2011; Stewart \& Dottolo, 2005). Also, the notion of 'excellence' and what it means to be a 'good academic' have been found to be masculine constructs (Lund, 2020a, 2020b).

Finally, a gendered division of work impedes women's careers in academia. Women spend more time on non-meriting tasks, such as teaching administration and service work, also referred to as the 'academic housework' (Angervall \& Beach, 2017; McFarlane \& Burg, 2019). Guarino and Borden (2017) have found that women faculty perform significantly more service work than men, controlling for rank, race/ethnicity and field or department.

In Japan, a study found that even though work-life balance created stress among men and women faculty because research was often disrupted by life events, job satisfaction was higher than in other types of work (Fuchigami \& Sugita, 2021). Yet another study found that taking childfcare leave did not diminish work performance (Takeishi, 2008). However, there is a need for more qualitative studies on academic life in Japan in general (Poole, 2010), especially with a gender perspective (Yukawa et al., 2019). In Norway, women also struggle with combining parenthood with academic jobs because of increasing workload (Thun, 2019). Women are also less able to fulfil the criteria for being a 'good academic,' because they are doing disproportionally more carework in the home and academic housework 
than men (Lund, 2020). Moreover, 'excellence' is still a gendered concept in Norwegian academia, where traditionally men-dominated disciplines are more frequently associated with excellency (Henningsen \& Liestøl, 2013).

To sum up, there has been many studies showing how women are excluded from academic careers in a multitude of ways. However, there have also been policy efforts aimed at getting more women to become professors. In the following text, we will outline some of the policy work that has taken place with regard to gender balance in professorial positions in Norway and Japan.

\section{Gender balance and academic career trajectories in Norway and Japan}

According to Husu (2015), Norway has had the most comprehensive and longstanding effort to improve gender equality in academia within Scandinavia. However, the share of women in professorial positions (as of 2021) is 34\%. The Humanities and Social Sciences have a better gender balance than STEM disciplines, even if there are large variations in the proportion of women professors between disciplines in the STEM fields and also within disciplines in the Humanities and Social Sciences (Sørensen \& Lagesen, submitted 2021).

In Japan, the percentage of women full professors is only $10.8 \%$, and even fewer are leaders in academia. The Japan Association of National Universities has established a Gender Equality Headquarters at each national university, with the goal to reduce gender imbalance in various areas. Also, a program to support research activities of women researchers was launched in 2013. More than $20 \%$ of women professors are working in the fields of the Humanities and Fine Arts and fewer than 5\% in the fields of Science and Engineering (Gender Equality Bureau Cabinet Office, 2015).

The typical academic career path in Norway goes from PhD to postdoctoral researcher to associate professor, eventually ending in a full professor position. Since 1993, Norwegian associate professors have been not only able to advance to professorial status by applying for vacant professor positions, but also by applying for a promotion to become professor on the basis of their research competence (Olsen et al., 2005).

There is also a third way - by applying for a vacant professorship in an open competition, being found competent but not the best qualified by the evaluation committee and then asking to be promoted to full professor in your own institution. Applying for promotion is now a more common strategy to become professor in Norway than applying for a vacant professorship (Kyvik, 2015). Due to having several pathways, there is a higher share of professors in Norway than in most other countries, and $40 \%$ of Norwegian faculty has a full professor position.

In Japan, there are also several ways to become a full professor. However, the most common way is that one applies to a tenure track position, which normally starts at the assistant professor or lecturer level. Based on the number of publications and years of teaching experience, the 
universities decide upon promotion to professor. Unlike in Norway where criteria for promotion are subject to national regulations, each Japanese university has its own criteria for promotion (Poole, 2010).

Support systems for women academics in Japan who are raising children differ widely by institution and the woman's professional status. In Japan, women are in general expected to care for their own children, as well as for other family members, such as the elderly. Full-time academic staff can get financial support for hiring babysitters or nursery teachers. They normally also have flexible working hours and can even work from home at times. However, this benefit does not typically extend to part-time academic staff. Also, in Japan a study found that having children did not statistically affect scientific output for women academics (Takeishi, 2008).

In Norway, the situation is different in that childcare facilities are more easily available for all, and parental leave schemes are extensive and designed to promote gender equality (Kvande \& Brandth, 2019). Having children while pursuing an academic career is also more common in Norway, compared to other countries (Vabø et al., 2014).

Even so, recent research in both contexts has also found that women academics struggle more with having children due to increased workload in academia (Thun, 2019), and that life-events create work-life balance stress for faculty (Fuchigami \& Sugita, 2021). Thus, it is pertinent to further explore what women and also men professors in the two contexts consider important for sustaining their academic careers.

\section{Data and methods}

We did in-depth qualitative interviews with 28 academics: 13 professors in Japan ( 8 women and 5 men) and 15 in Norway (10 women and 5 men). All interviewees were between 35 and 70 years old, with the majority being between 50 and 60. Interviews with professors in Norway were conducted in 2017 and 2018 as part of a larger research project aimed to improve gender balance among professors at a Norwegian university. The interviews with professors in Japan were conducted in 2020, as a spin off from the first project; it was made possible through the INTPART-funded research collaboration with Ochanomizu Women's University. The Norwegian professors were from the same university, while the professors working in Japan were recruited from eight different universities. These universities are located in different parts of Japan and cover a wide range of academic profiles. Interviewees in both countries represented different disciplines and research areas, and most of them worked in departments struggling with gender imbalance among full professors. Norwegian professors were recruited randomly and approached directly via e-mail. The Japanese professors were recruited by the assistance of mediators, who suggested potential participants and made the first-contact approaches. All participants were informed that the interview was part of a research project on gender balance. Almost all the professors we contacted accepted the invitation to participate. 
The interviews with the professors in Norway were done face to face by Norwegian researchers in Norwegian, the mother tongue of the interviewer and most of the interviewees. The interviews with the professors in Japan were done by the same Norwegian interviewers and conducted in English, a foreign language for both interviewers and interviewees. In most cases, the interview guide was shared with the interviewees beforehand. This made it possible for the interviewees to prepare and thus also helped reduce the language barriers. Due to the COVID-19 pandemic, interviews with Japanese professors were conducted online via zoom.

The interviews lasted from 30 to 60 minutes. We began by asking the interviewees to give an account of their personal career trajectories, and then we followed up with questions about how they perceived inclusion in this process. The questions were open-ended. All interviews were transcribed verbatim. In the next section, we explore what kind of inclusion the professors emphasised in their accounts of career trajectories. We start by analysing the main features of inclusion factors that were brought forward by our interviewees in both Norway and Japan. Each interview excerpt is cited with the interviewee's country and participant number. Then we will focus on what were seen as the greatest challenges. At the end of each section, we will discuss how our findings relate to the previous literature. In the last section, we offer some overall reflections on our findings.

\section{Passion, hard work and personal sacrifices}

Similar to much previous research, many of our interviewees in both Norway and Japan described the path to professorship as one of dedication and passion for academic work, as well as a willingness and ability to work hard and make what they saw as the necessary sacrifices for staying in academia. Such sacrifices could typically be long working hours and hence less time with family and friends, and/or long periods of hard and stressful work. For example, when asked to characterise her academic journey, a woman professor in Japan formulated it this way: 'It was very challenging. It was never easy. It took a long time and along the way I had to make a lot of tough priorities' (JAPAN 8).

However, such stories about hard work were also followed by engaged talk about research fields and teaching activities. A man professor put it like this: 'My career is exciting and fun!'. When he was asked directly if it had not also included 'hard work and efforts', he followed up with this answer:

Yes, effort is always important. We should work hard, but it's quite natural. I would say it's also my father's influence. I would see my father work hard at home. My friends in university also work at home hard. I think it is quite natural that I should work hard. It's no stress for me. (JAPAN 2) 
This emphasis on hard work was also highly present in the interviews with the Norwegian professors, both women and men. A telling example is to be found in the interview with a man professor in his early 60s:

The road to becoming professor has been cumbersome, tough and hard. Yes. And exhausting. But I have been so dedicated as a scholar, so I will claim it was worth it. But I am not sure I would have done it again. (NORWAY 3)

This quote clearly illustrates how academic work was considered rewarding, and so it compensated for the cumbersomeness of the process of becoming professor. But the quote also shows a good deal of ambivalence, emphasizing how hard such a process could be. Sacrifices made in order to get or keep a job in academia was also mentioned and were sometimes quite considerable. One international woman professor living in Norway gave birth to her children in another country, before she got a job in Norway. Since her children still lived there, she had to commute and spend much time away from her family. Still, she found the sacrifice worthwhile, because she loved the job:

I miss my children and my family very much. I find it difficult to leave when I am there. But so far it is going well, and I have a fantastic job. I enjoy the job immensely! But I do long for home sometimes (...) but thriving in the job is an extremely important factor. (NORWAY 14)

There were also other interviewees in the same situation, having chosen to work far away from their families. Others travelled together with family. Our data illustrated well how important it was to be geographically mobile to secure employment in academia. However, sometimes the decision to move was for scholarly reasons, such as being with the most relevant research group and/or being able to pursue their own research interests. Thus, working in an academic job was considered extremely valuable and enjoyable by many of our interviewees, both in Japan and Norway, and considered worth quite substantial sacrifices by many.

We did not find substantial differences between Japanese and Norwegian professors with regard to this strong dedication to their academic work, which was emphasised by most as a major motivation for their careers. Nor were there differences between men and women professors in this matter. Thus, passion and the attractiveness of a permanent job in academia are important inclusion qualities. In the next section, we will discuss what kind of supported inclusion was experienced by our interviewees. 


\section{Supported inclusion}

Many of our interviewees talked about how other people had been important for supporting them in their career. Many mentioned mentors or role models that either had inspired or encouraged them to pursue an academic career, either by evoking an interest for a particular topic or a research area, or by showing that barriers can be pushed. In the interviews with Japanese professors, this inspirational role was in quite a few cases played by parents or other family members who were academics or professors themselves. This opened a door to the academic world by showing that it is possible to pursue this line of work. This represents the cultural capital argued by Bourdieu (1988) The role of a parent in motivating their child to take up an academic career can be exemplified in the following interview extract with a professor in his late 40s explaining why he had chosen academia:

It's an important question! Maybe it's the influence of my father. My father looks quite happy because he worked with his students and got an exciting result. He was always excited to talk about the results that students gave him. (...) So, maybe when I was 10 years old, I said I will work in university someday. (JAPAN 2)

This way of framing the choice as inspired by a parent, usually a father, was more prominent in the interviews with Japanese professors than among our Norwegian interviewees. A Norwegian professor shared that seeing his father with the status of professor made the job seem more normal and less daunting:

One thing I have reflected on is that I have never really had a lot of respect for professors and other academics. When my father could be a professor, anybody could [laughs]. It wasn't something special, it was just a job and an okay one. (NORWAY 7)

We see that both interviewees presented their father's role as important for demonstrating that a professorial position is attractive but also obtainable. Having such a role model instilled motivation and confidence to embark on an academic career path.

Women professors often mentioned women in academia as role models who had been important for them in pursuing an academic career:

An older woman professor has been an important role model for me. She has three children, husband and a home, and then I thought, okay, it is possible. (NORWAY 1).

What was common in the accounts of women professors in Norway was that they saw it was possible to combine a job as a professor with having a family and caring for children. 


\section{Vivian Anette Lagesen et al.}

Many of our interviewees in both Norway and Japan talked about important mentors and supervisors who had guided them into an academic career by directly or indirectly giving them possibilities for career advancement. For many, this role was typically ascribed to their supervisor:

Interviewer: How did you succeed?

Professor: I have a very good mentor, [who is] a very good person, adviser and supervisor at this university. He was very supportive. I think that is an important reason (...) He gave me many chances to get positions and encouraged me. (...) He gave me possibilities at [my current] university, which was important for me. (JAPAN 1)

We see that support from a mentor was fundamental in this professor's career, and he credited much of his possibilities to have an academic career to this mentor. This was a very common narrative among the Japanese and Norwegian professors we interviewed, no matter their gender. Similarly, those who had not had such a mentor were often stressing this, indicating that having a mentor to guide and help a young scholar was perceived as crucial. A woman professor in Norway explained,

After my PhD, I have had to make it on my own, always. I believe I have been pretty strong, because I haven't had anyone to mentor me or to consult. I have, sort of, had to do everything myself. And it turned out well. (NORWAY 5)

While not having a mentor was considered a disadvantage, it also instilled a certain self-efficacy as well as pride in having become a 'self-made' professor. Most women professors in Norway, and to a lesser extent in Japan, talked about how they had been supported, and surprisingly few talked about overt gender discrimination as a pressing issue. One exception was a woman professor in Japan who had changed her field of research because of a lack of support from the men professors supervising her work. Entering a new field with a new mentor, who was a woman, made it possible for her to have an academic career:

The most crucial moment was deciding to change my specialties. It was my decision, but I think it was planned by men professors. So, the men professors they didn't teach me well, and I felt they were ignoring me. (...) When I changed my specialty, my mentor was a woman professor. (...) Women professors supported me a lot. I was helped by them. One of them who accepted me became the main judge in my doctoral thesis. I think they saved me in the academic journey. (JAPAN 3) 
These narratives demonstrate how mentors and role models played a crucial part in professors' careers. Others were also identified as important supporters along the way, such as colleagues, friends and, most importantly, family members. This was particularly evident in women professors' accounts, both in the Japanese and the Norwegian context. Support related to childcare was emphasised by most women professors, but by very few of the men professors.

Women professors in Norway often emphasised their partners as an important support, particularly in regard to having an equal division of domestic labour. Whether the interviewees found combining an academic career with parenthood to be stressful or not depended on whether their partners took on a fair share of the work:

I have had good support at home. An encouraging man and unproblematic children so-to-speak. So, there has not been heavy burdens there (NORWAY 9)

Another interviewee described this successful home dynamic as having a functional 'ground control' (NORWAY 8).

Having a reliable support system at home was not the only contextdependent difference in the data between women professors. Norwegian women professors often mentioned women-centred collectives and networks as an important source of motivation and support in their academic career. Encouragement and 'push' from leaders and supervisors to promote or stay in academia was frequently mentioned, as well as being awarded help and support by policy efforts, such as extra funding or extra leave to qualify for professorship. These kinds of effort were not mentioned often by women professors in Japan. But many mentioned their mothers as an important support, who had encouraged and supported them in their choices and their path to become a professor.

\section{Work-life balance}

As discussed in the theory section, women researchers often experience 'parental guilt' and a troublesome work-life balance. The experience of feeling torn between competing obligations at work and home, and the feelings of inadequacy this created, has been found among women across national settings (Acker and Armenti, 2004; Dickson, 2019; Ward \& WolfWendel, 2004). How did Norwegian and Japanese professors organise their personal and professional lives, and how did they make sense of their own time management and priorities in this regard? Were there gendered or contextual differences in how this was narrated?

Negotiations of time and priorities seemed to be different between men and women professors in both the Japanese and Norwegian contexts. In both contexts, the topic of work-life balance was negotiated with regard to 


\section{Vivian Anette Lagesen et al.}

societal gender norms on the one hand, and personal desires and lifechoices on the other hand. Pursuing an academic career while raising a family was considered challenging, but doable. Women professors with children in our sample described feeling conflicted about how best to divide their time and attention. A quote from a senior Norwegian woman professor illustrates this conflict well:

Really, my glorious years were from 1988 to ' 97 . In that period, I worked a lot, and I achieved a lot. Those ten years, without children, and few commitments, when my colleagues were my friends - during those years, I got a lot of work done. But, then, after ' 97 , the years with young children, was more like [being] in a fog. (NORWAY 1)

A Japanese woman professor similarly described her experience of raising young children while trying to maintain her academic work. When asked about crucial moments in her career, she replied,

I had to write papers at the same time [that I was immersed in] childbearing. When I was 30, I had to do two things: Writing papers and caring for my baby. It was a very tough time for me because I wanted to spend much more time with the child, but every day I thought, 'I have to write a paper, I have to do research.' (JAPAN 9)

In both Japan and Norway, the timing of having children in relation to career timing was portrayed as crucial. However, particularly in the Norwegian context, there were also many stories about combining work and family without much conflict. Some told how they combined high ambition research with motherhood:

The day I defended my PhD, I was pregnant. (...) After I had my first child, it only took a month before she was with me in the lab. With my second child, it took a week before he was with me in the lab. (...) You had to be at the research front, you had to keep up. (NORWAY 4)

This professor described herself as being 'equally hungry for work as for family.' She did not see these desires as contradictory but framed the situation as a matter of practical arrangement. However, we also heard stories of women who chose to work $80 \%$ in order to prioritise the family, which meant their career had taken a longer time to develop than others':

When you wait so long to have children, it becomes more important than anything in the world. That has been my priority, and I did not care if anyone bypassed me. (NORWAY 6) 
The flexibility of academic work was also emphasised by the Japanese women professors as something that made it possible to combine work with family. One Japanese woman professor also had a more critical outlook, claiming that the long working hours were far from efficient:

Well, the good part is we can decide some part of the job by ourselves. Many professors stay until midnight, but I come back home. In my opinion, we need to work certain hours and then we have to have private lives to refresh ourselves. That will make our concentration in the work[place] better. (...) Traditionally in Japanese society, if you stay longer, even if you are just drinking coffee maybe, people think that you are a hard worker, even if you are not really working. (JAPAN 11)

Thus, prioritising private lives could also be seen as a way to enhance, rather than diminish, the quality of professional work.

A difference here between the two contexts was that work-life balance was considered easier in Norway than in Japan. While some Japanese women professors said they had chosen to refrain from having children in order to advance in their careers, none of the Norwegian women professors expressed anything of the same. Moreover, international women professors in Norway found it to be an apt location for having children because of the good work-life balance opportunities:

Both my husband and I got good positions, and then we decided to stay on. One of the reasons was the balance between work and family. If I compare with my friends in my home country, I see that the balance is much, much better here... We have never been struggling, we don't have to have grandparents and nannies [help us]. (NORWAY 10)

Women professors in Norway seemed to take it for granted that they would be able to combine family and an academic career, due to the welfare services provided and their expectations of relatively equal shared responsibility in home-making. Most assumed that their partners would contribute fairly equally to household-related work. Japanese women professors, on the other hand, emphasised the need for support from one's extended family in order to pursue an academic career, as most couples in Japan still do not have an equal work division at home. Nonetheless, the position of professor was considered better suited for combining work with family compared with other professions because of the relatively flexible working conditions. 


\section{Vivian Anette Lagesen et al.}

\section{Concluding reflections}

The main aim of this chapter is to contribute to existing literature on what it is that include men and women to work in academia as a professor, and gendered and contextual aspects of inclusion factors. We have sought to do so by exploring how men and women professors in Norway and Japan accounted for how they entered and manage to remain in a top-level job in academia. Professors of both genders in both contexts conveyed a strong motivation for and desire to stay in academia. To achieve their goal, they had worked hard and endured precarious job situations; some had also made quite substantial sacrifices. Many highlighted the same factors as important for surviving in academia which were mentors or supervisors who had provided help and were important role models. Some interviewees who had not had much support described their trajectory as difficult and challenging but still rewarding. Thus, a shared common inclusion factor was a strong motivation to stay in academia, and the willingness to make the necessary choices to be able to do so. In some cases, this meant making substantial sacrifices. But, many had received much support and help in order to succeed. Such help and support may to some extent be accidental, which explains how academics often emphasise this notion of 'luck' to succeed in academia (Lindholm, 2004; Loveday, 2018).

If we disregard idiosyncratic factors, gender and context made a difference, primarily in terms of domestic work division and childcare. Women professors with children and families reported that they faced greater challenges than their male counterparts. This was handled by adapting and taking advantage of the opportunities for help that existed, which could be family members or childcare services. The latter was more easily available in Norway than in Japan. Also, many women professors in Norway emphasised that they had partners who contributed significantly to housework. This was not mentioned by Japanese women professors. Nevertheless, academia was perceived to offer a flexibility that made work-life balance a bit easier compared to other workplaces for women professors in Japan. Childcare was rarely mentioned as an impediment by men professors in either context. Moreover, Norwegian professors - men and women - assumed that academic careers could be combined with having children, which was not taken for granted among Japanese professors. However, compared to previous literature, surprisingly few women professors talked about a 'chilly climate' or explicit gender discrimination. This is a fruitful and important starting point for further studies.

\section{References}

Acker, S., \& Armenti, C. (2004). Sleepless in academia. Gender and Education, 16(1), 3-24.

Aiston, S.J., \& Jung, J. (2015). Women academics and research productivity: An international comparison. Gender and Education, 27(3), 205-220. 
Angervall, P. and Beach, D. (2017). Dividing academic work: Gender and academic career at Swedish universities. Gender and Education. https://doi.org/10.1080/ 09540253.2017.1401047

Bevan, V. \& Learmonth, M. (2012). 'I wouldn't say it's sexism, except that ... It's all these little subtle things': Healthcare scientists' accounts of gender in healthcare science laboratories. Social Studies of Science, 43(1), 136-158.

Blackburn, R.T., Chapman, D.W., \& Cameron, S.M. (1981). 'Cloning' in academe: Mentorship and academic careers. Research in Higher Education, 15(4), 315-327.

Bourdieu, P. (1988). Homo academicus. Polity Press.

Britton, D.M. (2017). Beyond the chilly climate: The salience of gender in women's academic careers. Gender \& Society, 31(1), 5-27.

Cannizzo, F. (2018). 'You've got to love what you do': Academic labour in a culture of authenticity. The Sociological Review, 66(1), 91-106.

Castaneda, M., \& Isgro, K. (Eds.). (2013). Mothers in academia. Columbia University Press.

Cohen, S., Hanna, P., Higham, J., Hopkins, D., \& Orchiston, C. (2020). Gender discourses in academic mobility. Gender, Work \& Organization, 27(2), 149-165.

Dickson, M. (2019). Academic motherhood in the United Arab Emirates. Gender, Place \& Culture, 26(5), 719-739.

Dubois-Shaik, F., \& Fusulier, B. (2017). Understanding gender inequality and the role of work/family interface in contemporary academia: An introduction. European Educational Research Journal, 16(2-3), 99-105.

Essed, P. (2004). Cloning amongst professors: Normativities and imagined homogeneities. NORA-Nordic Journal of Feminist and Gender Research, 12(2), 113-122.

Etzkowitz, H., Kemelgor, C., \& Uzzi, B. (2000). Athena unbound: The advancement of women in science and technology. Cambridge University Press.

Fox, M.F., Whittington, K., \& Linkova, M. (2017). Gender, (in)equity, and the scientific workforce. InU. Felt, R. Fouche, C. Miller, \& L. Smith-Doerr (Eds.), Handbook of science and technology studies (pp. 701-731). The MIT Press.

Fuchigami, Y., \& Sugita, N. (2021). Actual conditions of work-life balance and required supports of improvement of work environment on faculty members. Information and Technology in Education and Learning, 44(4), 409-418.

Fumasoli, T., Goastellec, G., \& Kehm, B.M. (2015). Academic careers and work in Europe: Trends, challenges, perspectives. InT. Fumasoli, G.Goastellec, \& B.M. Kehm (Eds.), Academic work and careers in Europe: Trends, challenges, perspectives (pp. 201-214). Springer.

Gender Equality Bureau Cabinet Office. (2015). 'White Paper on Gender Equality 2015'. Cabinet Office, Government of Japan (p. 87).

Ghodsee, K., \& Connelly, R. (2011). Professor mommy: Finding work-family balance in Academia. Rowman \& Littlefield.

Guarino, C.M., \& Borden, V.M. (2017). Faculty service loads and gender: Are women taking care of the academic family? Research in Higher Education, 58(6), 672-694.

Gutierrez, G.M., Niemann, Y.F., Carmen, G.G., \& A.P. Harris (Eds.). (2012). Presumed incompetent: The intersections of race and class for women in academia. Utah State University Press. 
Heffernan, T. (2020): Academic networks and career trajectory: 'There's no career in academia without networks.' Higher Education Research \& Development. https://doi.org/10.1080/07294360.2020.1799948

Heijstra, T., Bjarnason, T., \& Rafnsdóttir, G.L. (2015). Predictors of gender inequalities in the rank of full professor. Scandinavian Journal of Educational Research, 59(2), 214-230.

Henningsen, I. \& Liestøl, K. (2013). Likestilling i akademia. Er eksellense for menn og grand challenges for kvinner? [Gender equality in academia. Is excellence for men and grand challenges for women?]. Tidsskrift for Kjønnsforskning, 37(3-4), 348-361.

Hovdhaugen, E., Kyvik, S. \& Olsen, T.B. (2004). Kvinner og menn - Like muligheter. Om kvinner og menns karriereveier i akademia [Women and men Equal opportunities. On women and men's career opportunities in academia] (Report No. 12 NIFU).

Husu, L. (2015). A comprehensive national approach to promote gender equality in science: The case of Norway. In W. Pearson, L.M. Frehill \& C. L. McNeely (Eds.), Advancing women in science: An international perspective (pp. 329-331). Springer.

Ivancheva, M., Lynch, K., \& Keating, K. (2019). Precarity, gender and care in the neoliberal academy. Gender, Work \& Organization, 26(4), 448-462.

Kim, T. (2017). Academic mobility, transnational identity capital, and stratification under conditions of academic capitalism. Higher Education, 73(6), 981-997.

Kvande, E., \& Brandth, B. (2019). Designing parental leave for fathers - Promoting gender equality in working life. International Journal of Sociology and Social Policy, 40(5-6), 465-477. https://doi.org/10.1108/IJSSP-05-2019-0098

Kyvik, S. (2015). The academic career system in Norway. In M. Yudkevich, P.G. Altbach, \& L.E. Rumbley (Eds.), Young faculty in the 21st century: International perspectives (pp. 173-200). SUNY Press.

Le Feuvre, N., Bataille, P., Kradolfer, S., Carral, M.R., \& Sautier, M. (2019). The gendered diversification of academic career paths in comparative perspective. In A. Murgia, \& B. Poggio (Eds.), Gender and precarious research careers: A comparative analysis (pp. 50-80). Routledge. https://doi.org/10.1038/s41467018-07034-y

Lent, S.W., Brown, S.D., \& Hackett, G. (1994). Toward a unifying social cognitive theory of career and academic interest, choice, and performance. Journal of Vocational Behavior, 45(1), 79-122.

Lindholm, J.A. (2004). Pathways to the professoriate: The role of self, others, and environment in shaping academic career aspirations. The Journal of Higher Education, 75(6), 603-635.

Loveday, V. (2018). Luck, chance, and happenstance? Perceptions of success and failure amongst fixed-term academic staff in UK higher education. The British Journal of Sociology, 69(3), 758-772.

Lund, R. (2020a). The social organisation of boasting in the neoliberal university. Gender and Education, 32(4), 466-485.

Lund, R. (2020b). Becoming a professor requires saying 'No': Merging equality and quality agendas in a Norwegian gender balance project. In H.L. Smith, C. Henry, H. Etzkowitz H, \& A. Poulovassilis (Eds.), Gender, science and innovation (pp. 35-57). Edward Elgar Publishing. https://doi.org/10.4337/9781786438973. 
McFarlane, B. and Burg, D. (2019). Women professors and the academic housework trap. Journal of Higher Education and Management, 41(3), 262-274, https://doi.org/10.1080/1360080X.2019.1589682

Nonaka, C. (2020). Transnational identity: The struggles of being and becoming a Japanese female professor in a neo-kokusaika phase of Japan. Research in Comparative and International Education, 15(3), 234-251. https://doi.org/10. 1177/1745499920946201

Olsen, T.B., Kyvik, S, \& Hovdhaugen, E (2005). The Promotion to Full Professor Through Competition or by Individual Competence? Tertiary Education and Management, 11(4), 299-316. doi: 10.1007/s11233-005-0981-6

Ortlieb, R., \& Weiss, S. (2018). What makes academic careers less insecure? The role of individual-level antecedents. Higher Education, 76(4), 571-587. https:// doi.org/10.1007/s10734-017-0226-x

Ostrove J., Stewart, A.J., \& N.L. Curtin (2011). Social class and belonging: Implications for graduate students' career aspirations. The Journal of Higher Education, 82(6), 748-774. https://doi.org/101080/00221546.2011.11777226

Poole, G.S. (2010). The Japanese professor: An ethnography of a university faculty. Brill.

Riordan, S. (2011). Paths to success in senior management. In B. Bagihole, \& K. White (Eds.), Gender, power and management (pp. 110-139). Palgrave Macmillan.

Salminen-Karlsson, M., Wolffram, A., \& Almgren, N. (2018). Excellence, masculinity and work-life balance in academia: Voices from researchers in Germany and Sweden. International Journal of Gender, Science and Technology, 10(1), 52-71.

Savigny, H. (2014). Women, know your limits: Cultural sexism in academia. Gender and Education, 26(7), 794-809.

Sørensen, K.H. \& Lagesen, V.A. (manuscript submitted for publication). Diverging diversity: The changing gender balances among university faculty.

Stewart A.J., \& Dottolo A.L. (2005) Socialization to the academy: Coping with competing social identities. In G. Downey, J.S. Eccles, \& C.M. Chatman (Eds.), Navigating the future: Social identity, coping, and life tasks (pp. 167-187). Russell Sage Foundation.

Takeishi, E. (2008). Conditions necessary for offering childcare leave without sacrificing workplace performance. Lifelong Learning and Career Studies, 5, 59-73.

Thun, C. (2019). Excellent and gender equal? Academic motherhood and 'gender blindness' in Norwegian academia. Gender, Work \& Organization, 27(2), 166-180. https://doi.org/101111/gwao.12368

Tungesvik, R. (Ed.) (2021). Tilstandsrapport for høyere utdanning 2021 [Report about higher education]. Report no. 7.

Vabø, A., Padilla-González, E., Waagene, E., \& Næss, T. (2014). Gender and faculty internationalization. In Huang F., Finkelstein M., Rostan M. (Eds.), The internationalization of the academy. changes, realities and prospects (pp. 183-205). Springer.

Van Anders, S.M. (2004). Why the academic pipeline leaks: Fewer men than women perceive barriers to becoming professors. Sex Roles, 51(9-10), 511-521. https:// doi.org/101007/s11199-004-5461-9

Van Balen, B., Van Arensbergen, P., Van Der Weijden, I., \& Van Den Besselaar, P. (2012). Determinants of success in academic careers. Higher Education Policy, 25(3), 313-334. https://doi.org/10.1057/hep.2012.14 


\section{Vivian Anette Lagesen et al.}

Van den Brink, M., \& Benschop, Y. (2014). Gender in academic networking: The role of gatekeepers in professorial recruitment. Journal of Management Studies, 51(3), 460-492. https://doi.org/101111/joms.12060

Ward, K., \& Wolf-Wendel, L. (2004). Academic motherhood: Managing complex roles in research universities. The Review of Higher Education, 27(2), 233-257.

Ward, K., \& Wolf-Wendel, L. (2012). Academic motherhood: How faculty manage work and family. Rutgers University Press.

Yukawa, Y., Sakanashi, J., \& Murasawa, M. (2019). The contributions and potentialities of the study of the academic profession in Japan. The Journal of Educational Sociology, 104, 81-104. https://doi.org/101177/1028315308330848

Ylijoki, O.H. (2013). Boundary-work between work and life in the high-speed university. Studies in Higher Education, 38(2), 242-255. https://doi.org/10.1080/ 03075079.2011.577524 